\title{
Social Work, Democracy and Human Rights - What Follows from the Dignity of the Human Person?
}

Tadeusz Kamiński

Social work is both a practical activity and a field of academic reflection. In both these spheres it is based on reference to a coherent system of values, thus it has a clear axiological aspect. The present article will describe the problem of relationship between social work and human rights, the ideal of democracy, and also challenges presented to social work by recognition of the right to live. In the first part of the text I characterize social work as a profession promoting a definite set of values serving in this way to realize the basic human rights. Next I bring up the question of relations between democracy and social work. And finally, in the concluding part of the paper, I discuss the concept of the right to live and present possible dilemmas together with practical difficulties social workers face following the recognition of this right.

\section{Social work as a human rights profession}

A well-known international definition of social work, agreed on by the General Assembly of the International Federation of Social Workers in Montreal in 2000, provides the best confirmation of the fact that it is something more than efficient and professional assistance to people in need. As a professional activity, social work "promotes social change, problem-solving in human relationships and the empowerment and liberation of people to enhance well-being." ${ }^{1}$ Thus social work is not only about help, most frequently financial and psychological help to people who are unable to manage their lives effectively. Social workers want to change the world for the better. Working with individuals, families, groups and communities, they want to contribute to constructing a more just and - it could be said - more human world. This construction of a better world is based on an unambiguous declaration clearly expressed in the abovementioned definition that "Principles of human rights and social justice are fundamental to social work." 2

To understand the significance of democracy and human rights for the practice of social work, it is necessary to look closely at the system of values which constitutes the foundation of this kind of activity. The quoted international definition of social work includes explicit references to the sources of social work: it grew out "of humanitarian and democratic ideals, and its values are based on respect for the equality, worth, and dignity of all people. Since its beginnings over a century ago, social work practice has focused on meeting human needs and developing human potential. Human rights and social justice serve as the motivation and justification for social work action. In solidarity with those who are disadvantaged, the profession strives to alleviate poverty and to liberate vulnerable and oppressed people in order to promote social inclusion." ${ }^{3}$

The key values of social work therefore include the dignity and worth of each human person. And although existing ethical codes of social workers do not define the concept of dignity, 


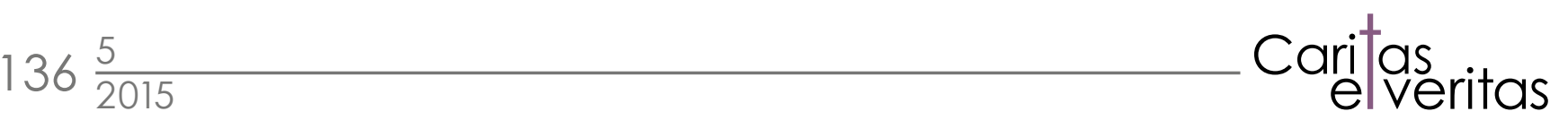

they use it to express the conviction that each human being is of exceptional and unique value. Frederick Reamer refers to the NASW Code of Ethics in which the principle of respect for the dignity and worth of each person is formulated as follows: "Social workers treat each person in a caring and respectful fashion, mindful of individual differences and cultural and ethnic diversity. Social workers promote client's socially responsible self-determination. Social workers seek to enhance client's capacity and opportunity to change and to address their own needs. Social workers are cognizant of their dual responsibility to clients and to the broader society. They seek to resolve conflicts between client's interests and the broader society's interests in a socially responsible manner consistent with the values, ethical principles and ethical standards of the profession." ${ }^{4}$ The concept of human dignity is of universal character, for according to Jim Ife: "Ideas of human dignity and worth, ideas that all people should be treated according to certain basic standards, ideas that people should be protected from what is frequently termed 'human rights abuse', and ideas of respect for the rights of others are not confined to the western intellectual tradition." ${ }^{5}$ In this approach it is thus possible to overcome thinking about human dignity in ethnocentric categories, which is especially important in the present days of globalization. For globalization encompasses not only the sphere of economy and politics, but also social work. ${ }^{6}$ It is in human dignity that the other values of social work are rooted. Their catalogues can be found in manuals of social work and above all in ethical codes adopted by associations of social workers in different countries.

Among the most important values stemming from the recognition of human dignity we should mention freedom, self-fulfillment, equality, social justice, well-being, care and social responsibility. ${ }^{7}$ One value of special importance in the context of reflections on the relationship between social work and human rights is social justice. In the NASW Code of Ethics quoted above we read: "Social workers pursue social change, particularly with and on behalf of vulnerable and oppressed individuals and groups of people. Social workers' social change efforts are focused primarily on issues of poverty, unemployment, discrimination and other forms of social injustice. These activities seek to promote sensitivity to and knowledge about oppression and cultural and ethnic diversity. Social workers strive to ensure access to needed information, services, and resources; equality of opportunity; and meaningful participation in decision making for all people." 8 As we can see, social justice as a value of social work includes all that creates living conditions which respect human dignity. Among the forms of injustice there are: poverty, unemployment and various forms of discrimination. Working for social justice, social workers become at the same time advocates of human rights. As has already been said, the international definition of social work includes a statement that: "human rights and social justice serve as the motivation and justification for social work action." Therefore, social work is described as a human rights profession. ${ }^{9}$ How are human rights understood in general, and in social work in particular?

According to the Universal Declaration of Human Rights of 10 December 1948 in Paris, all human beings are born free and equal in dignity and rights. ${ }^{10}$ Speaking of human rights we have

\footnotetext{
4 Frederic REAMER, Social Work Values and Ethics, New York: Columbia University Press, 2013, p. 27-28.

5 Jim IFE, Human Rights and Social Work. Towards Rights-Based Practice, Cambridge: Cambridge University Press, 2008, p. 5.

6 Cf. Karen LYONS, Globalization and Social Work: International and Local Implications, British Journal of Social Work, 36 (3)/2006, p. 365-380.

7 Tadeusz KAMIŃSKI, Etyka pracownika socjalnego, Częstochowa: Centrum Szkoleniowo-Wydawnicze Auxilio Venire, 2003 , p. 73-77.

8 Frederic REAMER, Social Work Values and Ethics, p. 27.

9 Christian SPATSCHECK, Soziale Arbeit als Menschenrechtsprofession. Begründung und Umsetzung eines professionellen Konzeptes, Sozial Extra, 32 (5-6)/2008, p. 6-9.

Silvia STAUB-BERNASCONI, Menschenrechte in ihrer Relevanz für dieSoziale Arbeit als Theorie und Praxis. Oder: Was haben Menschenrechte überhaupt in der Sozialen Arbeit zu suchen?, Widersprüche, 28 (107)/2008, p. 9-32.

10 Cf. (C) Universal Declaration of Human Rights (online), at: http://www.un.org/en/documents/udhr/, 1948, art. 1.
} 
in mind these rights to which a human is entitled by the sole fact of being a human being. They are therefore inherent rights of humans and do not depend on the will of the lawmaker and as such do not require any act of vesting, but rather an act of legal recognition. Because they are inherent (inborn) rights of humans, they cannot be acquired in the sense in which we acquire something we do not possess. People cannot relinquish their human rights or be deprived of them by any arbitrary decision. They are inalienable rights in the sense that a lawmaker cannot, as a rule, restrict or abolish them. A very important feature of human rights is their universality understood in such a way that they are fundamental by nature and everyone without exception is born with the same rights, regardless of their social or national background, marital status, race, color of the skin, gender, language, religion, political opinions or any other similar criteria. ${ }^{11}$

From the perspective of social work, the right to social security is of special importance. Theoreticians of human rights include this right in the category of so-called "social rights", consisting of claims which an individual or social group can hold against the society to ensure a dignified life for oneself. According to Henryk Skorowski, it is not only social assistance for the most needy, but many detailed rights a human is entitled to: work, just remuneration, ownership, share in income or profits, food and shelter, clothing and free participation in cultural heritage etc. ${ }^{12}$ A fairly detailed catalogue of social human rights is included in the Universal Declaration of Human Rights. It lists, among other things, the right to work, to just and favorable remuneration ensuring for oneself and one's family an existence worthy of human dignity, a standard of living adequate for the health and well-being of oneself and one's family, including food, clothing, housing and medical care and necessary social services, and the right to security in the event of unemployment, sickness, disability, widowhood, old age or other lack of livelihood in circumstances beyond one's control. ${ }^{13}$ Social rights protect goods and values associated both with livelihood and human needs resulting from the social nature of man. They pertain to this very sphere of human life with which social workers have to do every day. At the same time all these rights require that another, more fundamental right be guaranteed and protected, that is the right to life. But before I address this problem, it seems necessary to bring up the question of relation between social work and democracy.

\section{Democracy as a necessary condition for doing social work?}

Today democracy is recognized as the optimal form of government for it makes possible for citizens to exert the most influence on the government they are subjected to. There are, however, many models of democracy, all characterized by three core features. Firstly, democracy implies political equality and equal distribution of political power. Secondly, in democracy emphasis is placed on the importance of popular participation in the entire political process and this power is exercised through elected representatives (representative democracy). Thirdly, democracy is identified with rule in the public interest. ${ }^{14}$ Political scientists distinguish among three waves of democratization, indicating at the same time the desire of people living in authoritative and totalitarian countries to transport into a democratic system. ${ }^{15}$ Among the positive aspects of democracy we can indicate the following: it defends the freedom of an individual, restricting the scope of activity of governments; it promotes education and personal

11 Cf. Jim IFE, Human Rights and Social Work. Towards Rights-Based Practice, p. 15-16.

12 Cf. Henryk SKOROWSKI, Problematyka praw człowieka, Warszawa: Wydawnictwo Akademii Teologii Katolickiej, 1996, p. 27.

13 Cf. (c) Universal Declaration of Human Rights (online), at: http://www.un.org/en/documents/udhr/, 1948, art. 23, 25.

14 Cf. Andrew HEYWOOD, Key Concepts in Politics, Basingstoke: Palgrave Macmillan, 2000, p. 125.

15 Cf. Samuel P. HUNTINGTON, The Third Wave: Democratization in the Late 20th Century, Norman: University of Oklahoma Press, 1993. 
development of individuals; strengthens the community and social solidarity; it broadens the scope of personal rights and of the commons, guaranteeing that the government's policy respects the interests of the whole society; ensures political stability. ${ }^{16}$ Thus democracy appears to be valuable and could be recognized as a value defining the aspirations of persons and societies, especially of those who have experienced restrictions of freedom and violations of human rights. Is it valuable also for social workers and is it regarded by them as a necessary condition for social work practice?

The Code of Ethics of the National Associations of Social Workers in its original version of October 1960 contained the statement that "social work is based on humanitarian, democratic ideals". ${ }^{17}$ Democracy therefore could be understood as a set of ideal premises referring to a well-ordered society. ${ }^{18}$ Theoreticians and practitioners of social work generally agree with the opinion that the full development of man depends on the existing social system and social relations. ${ }^{19}$ For this reason, we are justified in thinking that the emergence and development of social work in Western European countries is not only the consequence of industrialization, but also of processes of democratization. ${ }^{20}$ Democratic conditions provided a valuable fodder for social work understood as an industrialized form of care for the poor, the socially excluded and persons with difficulties in normal social functioning within the society to fulfill its purposes. An important role was played by economic growth which made it possible for developed countries to allocate part of their national incomes to build a strong system of social protection. But another very important element seems to be the possibilities for open public debate on matters important for the whole society, characteristic of the democratic system. The plurality of opinions expresses itself also in that there are different versions of democratic practice. Ultimately, the extent of involvement of states in the social sphere depends on the established ideology and in consequence social workers execute their tasks in different varieties of welfare states regimes. ${ }^{21}$ As a consequence, the extent of relations between the caring and controlling functions of social work is diverse. There is no doubt, however, that democracy seems to create a favorable framework for social work purposes.

While reflecting on the importance of democracy for social work, it is worthwhile to take a closer look at the problem of practicing social work in non-democratic conditions. An interesting example of social work done in a country which does not meet the criteria of democracy is the People's Republic of China. Social work exists there not only as a practical activity, but also as a subject of study and scientific research. At the same time, the low standards of a social work cadre are emphasized. It was not until 2004 that social workers were granted a professional and official status by imposing formal requirements to raise the service standards of welfare staff. The first Chinese province to do so was Shanghai. But beneficiaries of social assistance are treated objectively and have almost no influence on the decisions about them. Social rights of people who apply for help are not protected by any institutions. People who are on welfare are subject to far-reaching control, and their names are made public. According to the government, these are necessary means to prevent social fraught. ${ }^{22}$ Social work, therefore, can

16 Cf. Andrew HEYWOOD, Key Concepts in Politics, p. 127.

17 (C) NASW, Code of Ethics adopted by the Delegate Assembly of the National Association of Social Workers (online), at: https://www. socialworkers.org/nasw/ethics/pdfs/NASW\%20Code\%20of\%20Ethics\%201960.pdf.

18 Cf. Peter SOMMERFELD, Demokratie und Soziale Arbeit - Auf dem Weg zu einer selbstbewussten und autonomen Profession?, in: Thomas GEISEN et al. (Hrsg.), Soziale Arbeit und Demokratie, Wiesbaden: Springer VS, 2013, p. 168-172.

19 Cf. Wolf R. WENDT, Ansprüche anerkennen und Ansprüche stellen, Blätter der Wohlfahrtspflege, 142 (10)/1995, p. 233.

$20 \mathrm{Cf}$. Thomas GEISEN et al., Soziale Arbeit und Demokratie: Zur notwendigen Bestimmung eines weitgehend unbestimmten Zusammenhangs,

in: Thomas GEISEN et al. (Hrsg.), Soziale Arbeit und Demokratie, Wiesbaden: Springer VS, 2013, p. 9.

21 Cf. Gøsta ESPING-ANDERSEN, Three Worlds of Welfare Capitalism, New Jersey: Princeton University Press, 1990.

22 Cf. Chak K. CHAN, Kinglun NGOK, David PHILIPS, Social Policy in China. Development and Well-Being, Bristol: The Policy Press: 2008, p. 71-85. 
be practiced in a non-democratic (or not fully democratic) country. But there is a danger that it may run counter to its basic mission itself. In a totalitarian country a social worker becomes a blind instrument of law and can be neither a constructive critic nor innovator. ${ }^{23}$ For this reason we are fully justified in maintaining that democracy is necessary for the establishment and development of social work.

In the context of the above arguments that democracy makes it possible for purposes of social work to be achieved, an important question arises: how does social work make use of the positive conditions created by democracy? This is the question of the pro-democratic or anti-democratic potential of social work. After all, social workers intervene in the lives of certain categories of people, and they do it in the name of the society, which expects them to act for solving social problems. The relationship between social work and democracy pertains in fact to the question of citizenship and availability of material, cultural and symbolic resources making it possible for citizenship to be fully exercised. In this perspective, the relations appear internally contradictory. ${ }^{24}$ On the one hand, social workers have the potential to support their beneficiaries in exercising their rights. One of the important purposes of social workers is to empower their clients and help them learn to take care of themselves. On the other hand, however, social work could be regarded as an element of social control over the "problematic" segments of the society. In helping them it at the same time imposes certain socially desired behavior. In this way it can contribute to the negation of universal citizenship, as people who benefit from social assistance become citizens of a second category, with restricted access to democratic institutions. Within the activation policy, beneficiaries are encouraged to be active and allowances are made dependent on their activity. At the same time, other citizens who care for themselves are induced to engage in social activities for the needy. This activation of the society is accompanied by a reduction of social benefits so far guaranteed by the state. It could therefore be said that a positive trend of making the social policy of the state more citizenry-infused is accompanied by the marginalization of some part of its beneficiaries. Conditions created by the democratic system do not guarantee that social work will help beneficiaries become self-dependent and subjective.

It follows, however, from the literature on the analyzed subject that it is not only social work that needs democracy, but also democracy needs social work. As Gordon Allport wrote, "social service can make itself not only the servant but also the prophet of democracy. And today, as never before, democracy needs both servants and prophets." ${ }^{25}$ Social workers have direct contact with the most handicapped and wronged individuals and groups of the society. They can see all the shortcomings and defects of the system that by its very essence is supposed to be open and just. Seeing poverty and humiliation every day, they can also identify the causes of negative social phenomena. And thanks to that, they can indicate to political decision-makers what should be improved in the failing mechanism of democracy. Social workers have been trying to play this role since the beginning, demanding social reforms. Some of them are quite radical, as illustrated by David Howe (2009). In fact, we are justified in saying that they are both servants and prophets of democracy. Yet there are some social problems, towards which the voice of social workers is not unanimous and the radicalism of their activity could be directed in two opposite directions. Such special challenge is presented to social workers by the recognition and implementation of the right to life.

23 Cf. Krzysztof PIĄTEK, Związki pomiędzy polityką i polityką społeczną a pracą socjalną, in: Tadeusz KAMIŃSKI (ed.), Politologia. Polityka społeczna. Praca socjalna, Warszawa: Wydawnictwo UKSW, 2001, p. 19-20.

24 Cf. Thomas WAGNER, Soziale Arbeit als Ort der (Post)Demokratisierung von Gesellschaft?, in: Thomas GEISEN et al. (Hrsg.), Soziale Arbeit und Demokratie, Wiesbaden: Springer VS, 2013, p. 40-41.

25 Gordon ALLPORT, Personality and Social Encounter, Boston: Beacon Press, 1960, p. 292. 


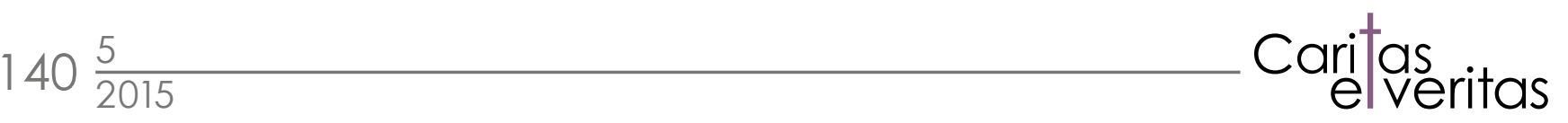

\section{The right to life - a challenge for social workers}

The right to life is the most basic of all human rights. According to the already quoted Universal Declaration of Human Rights, "[e]veryone has the right to life." ${ }^{26}$ But this at first glance obvious statement raises many controversies. The most explicit examples of these controversies are disputes about abortion, euthanasia or capital punishment. So, how to understand the right to life? Is it really an absolute and unconditional right of every human being? What problems does it pose to social work and in what way can social work contribute to the observance of the right to life? I will attempt to answer these questions in this last part of my text.

As has already been said, social work places special emphasis on the dignity and worth of every human being. Unfortunately, it is very hard to find in textbooks on social work an unambiguous statement saying that human life has a special worth and value for social workers. But John Haines, for instance, in his book on social intervention wrote not only about the value but about the sanctity of all human life, ${ }^{27}$ which should be noted as exceptional for the literature on social work. What is quite common, however, is the question of quality of life and right to have worthy living conditions. The very concept of living conditions that respect human dignity is imprecise. But, considering the rights included in the already quoted Universal Declaration of Human Rights, it could be said that for these conditions to be created it is necessary to meet material needs at an adequate level, but also to offer possibilities of social functioning for each human. In the recommendations included in the Council of Europe project on human dignity and social exclusion ${ }^{28}$ it was indicated that it should be necessary to provide universal and equal access to health care, shelter, employment, social security and education. But what does "adequate level" of meeting the needs mean? At the moment, I do not resolve this problem. It is enough to say that this level depends to a large extent on belief and convictions on the subject within the society at the given time. Thus its nature is relative.

The concept of the right to life is much more precise. First and foremost, it includes an obvious moral duty not to kill other human beings. No one could be arbitrarily deprived of their life and the right to life should be protected by law. A detailed content of the right to life indicates some additional aspects. There is the right to integrity and inviolability of the physical body. In addition, the right to life implies the right to preserve health and physical development. In the broadest sense of the word, the right to life includes also the living conditions of persons, from providing a minimum subsistence to the right to live in peace. It follows, therefore, that the content of the right to life includes a whole set of detailed provisions. ${ }^{29}$ What is controversial, however, is the scope of application of the right to life. The absoluteness of the right to life is questioned for unborn children and the personal rights of the mother (especially the argument of poverty and poor living conditions) are regarded as more important than the right to life of the unborn child. In debates on euthanasia attention is paid to the right to die with dignity, but understood in a specific way, that is as the right to intentionally ending a life to relieve pain and suffering. Another controversial example of how the right to life is questioned is the death penalty. In the emotional sense it is easy to accept that murderers, for example, have forfeited their right to life. But the problem is that - as it has been already said - in the light of valid documents on the human rights, all human beings without exception have the right to life. In their everyday practice social workers often deal with unwanted or unexpected pregnancies, not

26 (c) Universal Declaration of Human Rights, 1948, art. 3.

27 Cf. John HAINES, Interventionsprozesse in der sozialen Arbeit. Die Doppelstrategie gegenüber Betroffenen und ihrem gesellschaftlichen Umfeld, Freiburg i.Br.: Lambertus, 1978, p. 19.

28 Cf. @ Council of Europe (1998), Summary of the Project Human Dignity and Social Exclusion (online), at: https://wcd.coe.int/ViewDoc. jsp?id $=488075 \&$ Site $=$ COE.

29 Cf. Henryk SKOROWSKI H, Problematyka praw człowieka, p. 64-71. 
only of teenagers but also adults. And for this reason I will focus on the problem of protection of unborn life as a special challenge for social workers in the context of the human right to life.

The attitudes of social workers towards the problem of unwanted or unexpected pregnancy certainly have their roots in the moral outlook of the individual persons. A certain role is played by the religious factor. On the other hand, the social worker as professional helper must act after a reliable appraisal of the situation of the client. There is no one universal problem-solving model for an unwanted or unexpected pregnancy. Proposals offered in the literature on the subject, but also in comments of practitioners, could be reduced to three general variants. The first one is when such pregnancy presents a set of challenges that could be resolved without resorting to abortion. The second is when the scale of challenges and complications facing the pregnant woman (especially teenager or a single woman) is so great that not everyone could cope. Sometimes abortion could be the only solution. The third variant emphasizes mainly the problem of the so-called right to abortion and reproductive health. Let us take a closer look at these three proposals.

Assuming that the problem could be resolved without resorting to abortion, there are many tasks facing social workers and volunteers, such as pregnancy counseling for teenagers, including young fathers, and their education on parental responsibilities and how to fulfill them. What is important here is support for young mothers to adapt to the new life situation they are not prepared for. Work with the parents of the young mothers is also necessary, in order to make them have a role in child-rearing as well. These are important elements in preparations for the birth of the child. After the birth, the support is maintained and it could include getting young mothers back to school, preparing them for gainful employment and achieving financial independence. In a situation when there is no actual possibility of bringing up the child, the role of the social worker is to assist the young parents in all aspects of the adoption procedures. ${ }^{30}$ This variant does not underestimate the difficult situation of the young mother but seeks solutions which would make it possible to reconcile the value of life of the unborn child and developmental prospects of the mother. The adoption of this variant does not require an explicit pro-life or pro-choice declaration. It is based on the conviction that in social work it is important to look for optimal solutions offering maximum advantages and doing minimum harm.

The second variant described is based on the assumption that the unwanted or unplanned pregnancy could ruin the life of a young mother. It limits her perspectives for personal development and closes the possibilities for shaping her life. It is a kind of crisis situation. In consequence, abortion is indicated as one of the possible solutions. It is emphasized at the same time that the ultimate decision must be made by the girl herself, regardless of her age. In order to make a fully conscious decision she must be informed about various possibilities and the social worker is expected to remain neutral. As Lilian Pike Cain writes, "the role of the social worker who interviews an adolescent prior to an abortion is that of a facilitator. By discussing the possible alternatives that are open to her, the girl is able to realize that she has a choice and that her final decision will be the one that is the best for her at this juncture in her life." 31 The final decision could be to give birth to the child, to offer the child for adoption, or to undergo abortion. In the last case the social worker must support the teenager by helping her go through this difficult period of her life and understand that it is one of the experiences on

30 Cf. Brenda L. DUBOIS, Karla K. MILEY, Social Work. An Empowering Profession, Boston: Allyn\&Bacon, 2002, p. 400ff.

31 Lillian P. CAIN, Social Worker's Role in Teenage Abortions, Social Work, 24 (1)1979, p. 56. 


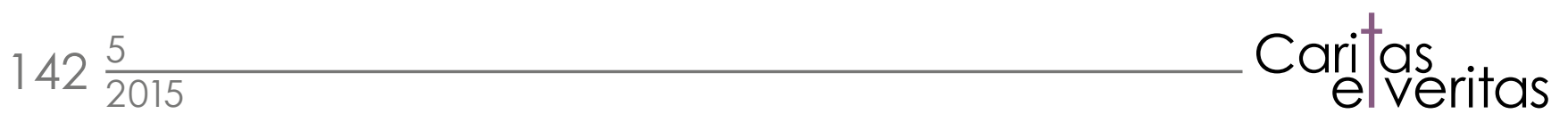

her way to adulthood. Cain stresses, however, that "although an abortion may end the crisis, it seldom resolves the original conflict." 32

A specific feature of the discussion about abortion is that it is regarded as one of the rights of women and considered in a broader sense of so-called reproductive health. This is the third variant of the problem analyzed here. Social workers are called to bring this question up in the fight for social justice: "The profession of social work is grounded in concepts of social justice, and its policy statement in this area specifically outlines the importance of access to abortion as a human right for women. Social workers can no longer ignore their obligation to seek social justice through policy practice in this area as the need is great and the time is now." 33 This call is urgent for the exercise of the right to abortion is restricted even in countries where women formally have the right to abortion. These restrictions exist directly in law regulations and their practical implementation. In the United States they especially apply to poor women, who have to use clinics financed with public funds. ${ }^{34}$ Nevertheless, social work serves mainly these social categories of people: the poor, the socially excluded, those unable to care for themselves. If we regard abortion as an inalienable right of women, it should be an ethical duty of social worker to facilitate access to it. From the perspective of anti-abortionists this sounds paradoxical. But pro-choice advocates go even further and not only call on social workers to defend the reproductive rights. They warn against the reaction of pro-lifers: "Everyone is aware of the terrorist activities of conservative anti-choice groups, who harass and even endanger clients and workers who seek and enable choice." ${ }^{35}$ In such a perspective fervent defenders of human life are regarded as a real threat to social workers. Those who defend the right to life are thus regarded as opponents of human rights. There is no discussion on how to help women having unwanted or unplanned pregnancies at this level. Abortion is the simplest and most obvious solution, based on an appeal to... human rights.

\section{Conclusions}

Social work could be regarded as a profession implementing human rights. Every day social workers work with individuals whose fundamental rights are threatened or violated. The optimal political context for the realization of human rights seems to be democracy. It could also provide a suitable framework for doing social work. As follows from the analyses made in the present text, even such an obvious human right as the right to life provokes opposing reactions in the community of social workers. This is best evinced by the example of work with women having unwanted/unplanned pregnancy. Some regard unborn life as a value in itself and help the women to solve their problems respecting this value. Others regard abortion as a right of women and they recognize as their mission to assist women in exercising this right. Both the former and the latter appeal to human rights and use the formal frames of democracy.

\section{Social Work, Democracy and Human Rights - What Follows from the Dignity of the Human Person?}

Abstract The paper presents social work as a means of implementing human rights and democracy as

33 Gretchen E. ELY, Catherine N. DULMUS, Abortion Policy and Vulnerable Women in the United States: A Call for Social Work Policy Practice, Journal of Human Behavior in the Social Environment, 20 (5)/2010, p. 669-670.

34 Cf. Alice LIEBERMAN, Liane V. DAVIS, The Role of Social Work in the Defense of Reproductive Rights, Social Work, 37 (4)/1992, p. 365-371. 
a necessary framework of its successful realization. It then focuses on one particular human right, whose observation by social workers is a matter of controversy, namely the right to life. It describes three different strategies a social worker can assume when dealing with a case of unwanted or unexpected pregnancy and concludes that all appeal to human rights and use the formal frames of democracy.

Keywords social work, democracy, human rights, right to life, abortion 